\title{
PERFORMANCE STUDIES ON DIESEL ENGINE USING BLENDS OF COCONUT DE-OILED CAKE AND METHYL ESTERS OF JATROPHA
}

\author{
S. Sendilvelan ${ }^{1, *}$ and K. Bhaskar ${ }^{2}$ \\ ${ }^{1}$ Department of Mechanical Engineering, Dr. M.G.R. Educational and Research Institute, \\ University, Chennai-600095, (Tamilnadu) India \\ ${ }^{2}$ Department of Automobile Engineering, Rajalakshmi Engineering College, \\ Chennai-602105, (Tamilnadu) India \\ *E-mail: sendilvelan.mech@drmgrdu.ac.in
}

\begin{abstract}
Increasing environmental concern, depleting oil and natural resources are the driving forces in promoting biodiesel as an alternate fuel. Vegetable oils are considered as good alternatives to diesel as their properties are comparable to diesel and at present biodiesel are commercially produced from vegetable oils by esterification processes. Since most of these oils are edible, its cost restricts the usage. The de-oiled cakes after crushing the seeds contain around $2 \%$ of oil with less fatty materials has been considered in this study, by complementing with diesel fuel. The fuel is prepared by adding dry coconut de-oiled cake (Coc) powder at 15 percent by weight with diesel, and methyl esters of Jatropha (MEJ), while Jatropha seeds which are transesterified and blended with diesel in 15\% percent. Experimental results reveal that the fuel has the potential in reducing the smoke levels, carbon monoxide, unburnt hydrocarbon emissions simultaneously along with a marginal increase in brake thermal efficiency and oxides of nitrogen.

Keywords: Biodiesel, Coconut De-Oiled Cake, Methyl Esters of Jatropha, Emission Study, Diesel Engine

(C) RASĀYAN. All rights reserved
\end{abstract}

\section{INTRODUCTION}

The petroleum based diesel fuel needs to be substituted with alternate fuel to meet the energy demands in the future for developing countries. ${ }^{1}$ The fossil fuels are depleting drastically which increases the demand in the international market that affects the economy of the developing countries like India. ${ }^{2}$ Thus, an alternate energy source to be identified to overcome the problems with the petroleum based diesel fuel. One such energy source is fuel derived from vegetable oil that is bio diesel. Many biodiesels in the form of esters are being experimented to suit the diesel engine without any major engine modification. Pure coconut oil usage in diesel engine shows lesser smoke, carbon monoxide (CO), hydrocarbon (HC) emissions compared to diesel fuel since it has oxygen molecules which result in enhanced oxidation. ${ }^{3}$ With pure coconut oil and diesel fuel blends in an automotive DI diesel engine increase in brake power and net heat release rate with a reduction in emissions such as $\mathrm{HC}, \mathrm{CO}$, NOx, smoke are reported for coconut oil in the fuel blend. ${ }^{4}$ The increase in brake power is expected due to larger fuel droplets and oxygen content in coconut oil, which contribute to better combustion. ${ }^{5}$ When the coconut oil in the fuel is increased above $20 \%$ decrease in performance was reported which is attributed to lower calorific value, with a reduction in emissions. ${ }^{6,7}$ Even though the coconut oil gives a significant reduction in emission, it is edible oil based fuel thus cost of the oil restricts its use as a fuel for replacing diesel. The Coconut De-Oiled Cake (Coc) was investigated by a couple of authors in a variable speed DI diesel engine and their results show that emissions are lowest for Coc compared to diesel. ${ }^{8,9}$ The fuel can be categorized as oxygenated fuel since it has oxygen molecules and this oxygen can enhance the oxidation during the combustion resulting in lesser $\mathrm{CO}, \mathrm{HC}$ and smoke emission. ${ }^{10,11}$ The de-oiled cakes contains oxygen with very minimum fatty substances, and hence in this work, a fuel is produced by adding $15 \%$ of de-oiled cake with diesel. ${ }^{12,13}$ 
Biodiesel derived from the trans-esterification of fats and oils is a possible fuel for diesel engines, Methyl Esters of Jatropha (MEJ) is derived through transesterification process. ${ }^{14,15}$ Properties of this fuel are comparable to that of diesel and can be used directly to run the existing diesel engines or as a blend with crude oil diesel. ${ }^{16}$ Biodiesel is renewable, biodegradable and non-toxic, with diesel it increases fuel lubricity and operates in compression ignition engines with little or no modification ${ }^{17}$. In the present work, nonedible coconut de oiled cake and the methyl ester of Jatropha blends with diesel were compared for the performance and emission characteristics. Experimental investigations have been carried out to examine performance and emissions of $15 \%$ MEJ blend and $15 \%$ de-oiled coconut cake blends with diesel in comparison to sole diesel fuel.

\section{EXPERIMENTAL}

The major problems in the direct use of vegetable oil as fuel in the diesel engine are fuel filter plugging, choking of injector nozzles, sticking of piston rings and crankcase oil dilution. The kinematic viscosity of the vegetable oil is generally higher than diesel fuel and can be brought down by various techniques such as preheating, blending, emulsification and transesterification. The de-oiled cake of edible and non-edible oils is now used as cattle feed and manure which is a good oxidizer having less fat and will be dissolved in diesel up to some extent. The de oiled cake was dried and pulverized and the fuel was prepared by adding a known amount of pulverized de oiled cake with a known amount of diesel and the blend can settle for 5 to 7 days to get a completely dissolved blend. The sediments are filtered and the fuel is used in a diesel engine without any engine modification. The properties of the diesel fuel, coconut oil, coconut oil blends and Coc blends were measured and given in Table- 1 and 2.

Table-1: Properties of Coconut De-Oiled Cake (Coc) Blends

\begin{tabular}{l|c|c|c|c}
\hline \multicolumn{1}{c|}{ Properties } & Diesel & $\begin{array}{c}\text { Limits as per } \\
\text { IS 15607-2005 } \\
\text { ASTM D6751 }\end{array}$ & $\begin{array}{c}\text { Coconut De- } \\
\text { Oiled Cake } \\
\text { Blend (15\%) }\end{array}$ & $\begin{array}{c}\text { MEJ Blend } \\
(15 \%)\end{array}$ \\
\hline Kinematic Viscosity at $40^{\circ} \mathrm{C}(\mathrm{cSt})$ & 3.366 & $1.9-6.0$ & 4.2 & 4.5 \\
\hline Calorific value $(\mathrm{kJ} / \mathrm{Kg})$ & 42,000 & - & 40,055 & 39,640 \\
\hline Density $\left(\mathrm{kg} / \mathrm{m}^{3}\right)$ & 830 & $860-900$ & 872 & 882 \\
\hline Calculated Cetane Index & 50 & - & 53 & 54 \\
\hline Flash Point $\left({ }^{\circ} \mathrm{C}\right)$ & 54 & 120 min & 154 & 160 \\
\hline
\end{tabular}

The experiment was conducted on Kirloskar, four strokes, single cylinder, air cooled diesel engine. The rated power of the engine was $5.2 \mathrm{~kW}$ at $1500 \mathrm{rpm}$. The engine was operated at a constant speed of 1500 $\mathrm{rpm}$ and standard injection pressure of 200 bar pressure. Experiments were conducted with different blends of diesel with coconut de-oiled cake powder (Coc) and Methyl Esters of Jatropha (MEJ) ranging from 15\% by weight to sole fuel. Readings were taken, when the engine was operated at a constant speed of $1500 \mathrm{rpm}$ for all loads. The performance of the engine was evaluated in terms of brake thermal efficiency, specific fuel consumption from the above parameters. The combustion characteristics like cylinder pressure and heat release rate were noted for different blends.

Table-2: Comparison of the Fatty Acid Composition (wt \%) of Coconut De-Oiled Cake (Coc) and Methyl Esters of Jatropha (MEJ)

\begin{tabular}{l|c|c|c|c}
\hline Types of Fatty Acids & Chemical Structure & Type & MEJ & Coc \\
\hline Palmitic Acid & C16:0 & S & 15.30 & 12.6 \\
\hline Stearic Acid & C18:0 & S & 9.60 & 3.99 \\
\hline Oleic Acid & C18:1 & US & 40.60 & 10.54 \\
\hline Linoleic Acid & C18:2 & US & 33.40 & 2.58 \\
\hline
\end{tabular}


RASĀYAN J. Chem.

Vol. 10 | No. 3 |1043 - 1049 | July - September | 2017

\begin{tabular}{l|c|c|c|c}
\hline Linolenic Acid & C18:3 & US & 0.30 & 0.01 \\
\hline Arachidic Acid & C20:0 & S & - & 0.2 \\
\hline Saturated Fatty Acids (S) & C14-C18 & - & 25.60 & 86.75 \\
\hline $\begin{array}{l}\text { Unsaturated Fatty Acids } \\
\text { (US) }\end{array}$ & C18:1,2,3 & - & 74.30 & 13.25 \\
\hline
\end{tabular}

\section{Carbon monoxide emissions}

\section{RESULTS AND DISCUSSION}

Figure-1 shows that the variation of Carbon monoxide (CO) emission with the load. Formation of $\mathrm{CO}$ is due to insufficiency oxygen and time in the combustion chamber during the combustion process. In general, the $\mathrm{CO}$ emissions are low for diesel engines as they operated with lean mixtures.

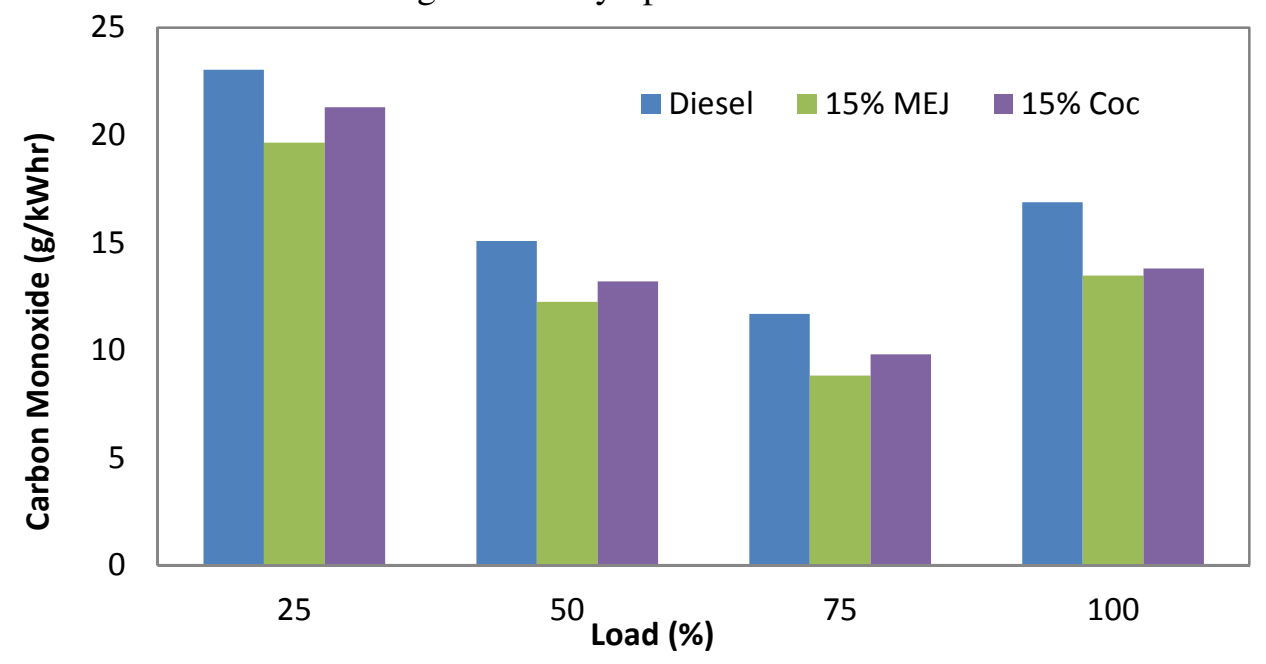

Fig.-1: Variation of Carbon Monoxide Emission Vs Load

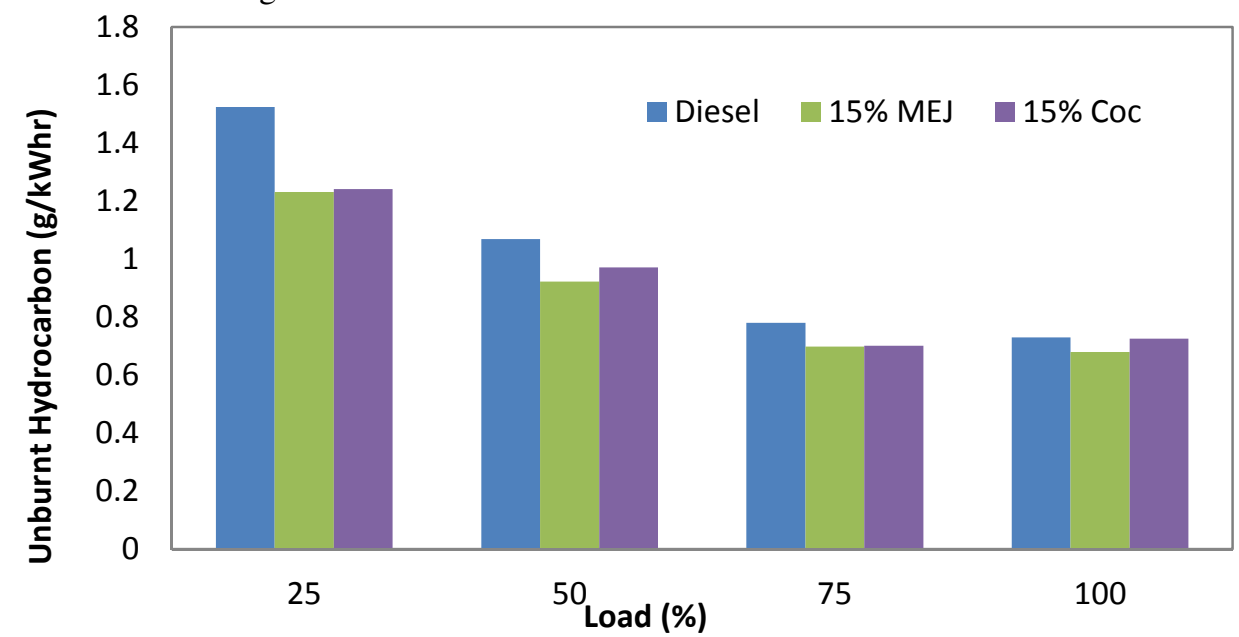

Fig.-2: Variation of Unburnt Hydrocarbon Emission Vs Load

It is observed that both $15 \% \mathrm{MEJ}$ and $15 \%$ Coc blends show lower CO compared to diesel at all the loads. The CO emission varies from $19.64 \mathrm{~g} / \mathrm{kWh}$ at $25 \%$ of load to $13.47 \mathrm{~g} / \mathrm{kWh}$ for $15 \%$ MEJ blends at full load while $15 \%$ Coc CO emission varies from $21.3 \mathrm{~g} / \mathrm{kWh}$ to $13.8 \mathrm{~g} / \mathrm{kWh}$. Diesel fuel shows higher CO emission which varies from $23.04 \mathrm{~g} / \mathrm{kWh}$ at $25 \%$ of load to $16.87 \mathrm{~g} / \mathrm{kWh}$ at full load. Due to the intrinsic oxygen content in MEJ and Coc, the oxygen available for oxidation of $\mathrm{CO}$ is more compared to diesel which results in reduced $\mathrm{CO}$ emission. 


\section{Unburnt hydrocarbon emissions}

The emissions of UBHC, CO and NOx are measured using AVL five gas analyzer and converted to $\mathrm{g} / \mathrm{kWh}$. The variation of Unburnt Hydrocarbons (UBHC) with the load for 15\% MEJ and 15\% Coc compared with that of diesel is shown in Fig.-2. It is observed that UBHC emissions decrease as the load increases for all the fuels tested. The oxygen surrounding the fuel droplets would take the relatively larger time to assist the combustion of fuel droplets; there is a reduction in UBHC emissions for all loads. It can be observed that Coc blends show marginally higher UBHC emissions compared to MEJ.

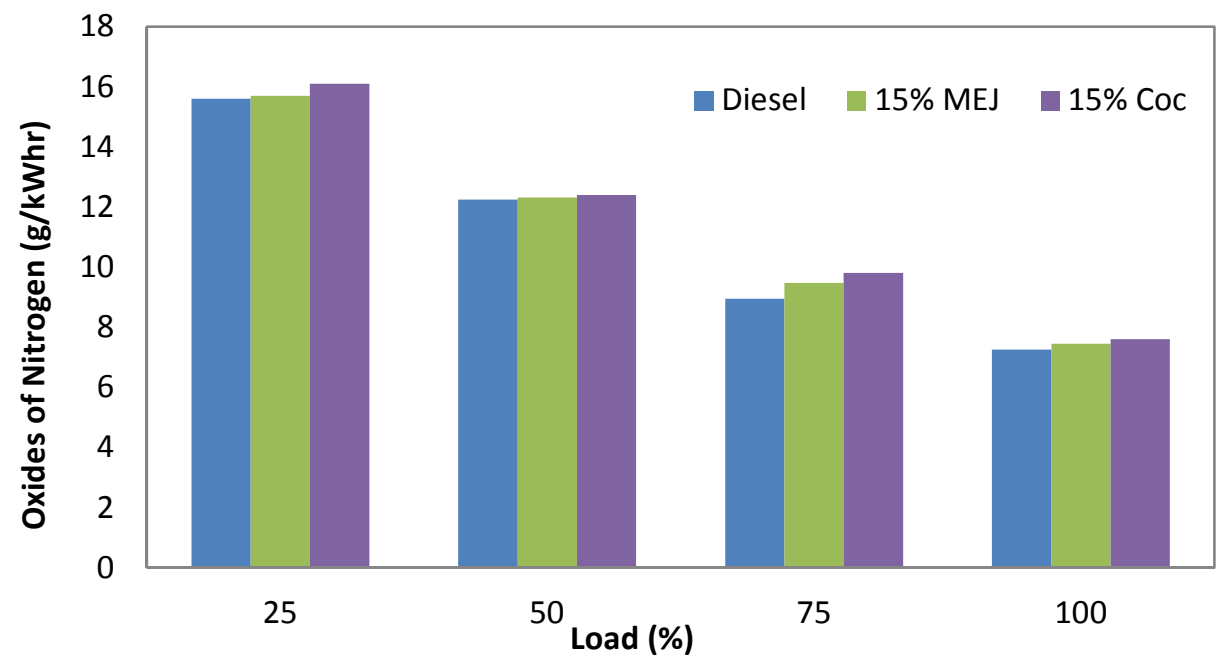

Fig.-3: Variation of Oxides of Nitrogen Emission Vs Load

\section{Oxides of nitrogen emissions}

Oxides of nitrogen $\left(\mathrm{NO}_{\mathrm{x}}\right)$ consist of nitric oxide $(\mathrm{NO})$ and nitrogen dioxide $\left(\mathrm{NO}_{2}\right)$. Nitric oxide is predominant in the oxides of nitrogen produced inside the engine cylinder. The variation of $\mathrm{NO}_{\mathrm{x}}$ emission with the load for these fuels tested is shown in Fig.-3. A gradual increase in the emission of $\mathrm{NO}_{\mathrm{x}}$ is observed at all loads except at 25\% load. As methyl esters and Coc are oxygenated fuels their use results in higher combustion temperature and higher $\mathrm{NO}_{\mathrm{x}}$ emission at higher loads ${ }^{18}$. The $\mathrm{NO}_{\mathrm{x}}$ emission varies from 15.095 $\mathrm{g} / \mathrm{kWh}$ at $25 \%$ of load to $7.454 \mathrm{~g} / \mathrm{kWh}$ for $15 \%$ MEJ blend at full load. $\mathrm{NO}_{\mathrm{x}}$ emission varies from 15.4 $\mathrm{g} / \mathrm{kWh}$ to $7.6 \mathrm{~g} / \mathrm{kWh}$ for $15 \%$ Coc. Diesel fuel show higher $\mathrm{NO}_{\mathrm{x}}$ emissions which vary from $15.6 \mathrm{~g} / \mathrm{kWh}$ at $25 \%$ of load to $7.25 \mathrm{~g} / \mathrm{kWh}$ at full load. Coc blends show higher values of $\mathrm{NO}_{\mathrm{x}}$ emissions compared to MEJ blends.

\section{Smoke emissions}

Diesel particulate matter consists higher agglomerated solid carbonaceous material, ash, volatile organic and sulfur compounds resulting from incomplete combustion of hydrocarbons present in the fuel. The increase in smoke emissions for diesel fuel is also due to higher boiling point and thermal stability of aromatic hydrocarbons present in it. It can be observed that smoke emission increase with an increase in power output for all the fuels due to lower air fuel ratio at higher loads as shown in Fig. -4 . The smoke emissions at full load for diesel, 15\% MEJ and $15 \%$ Coc are $166 \mathrm{mg} / \mathrm{m}^{3}, 123 \mathrm{~g} / \mathrm{m}^{3}$ and $150 \mathrm{~g} / \mathrm{m}^{3}$ respectively.

Figure-5 shows the variation of cylinder pressure with crank angle at rated power output for diesel, $15 \%$ MEJ and 15\% Coc oil respectively. In-cylinder peak pressure is higher for 15\% MEJ and 15\% Coc compared to diesel. The cylinder pressures at all the crank angles are higher for both the blends compared to diesel due to their higher cetane number and shorter ignition delay compared to diesel. Hence, combustion starts early in the case of methyl ester blend and results in higher cylinder pressure. Methyl esters are oxygenated fuels and their higher oxygen content results in better combustion and higher cylinder 
pressure. It is observed that both the methyl ester blends show marginally higher in-cylinder pressure during the expansion stroke due to the late burning of higher fatty acid components present in them.

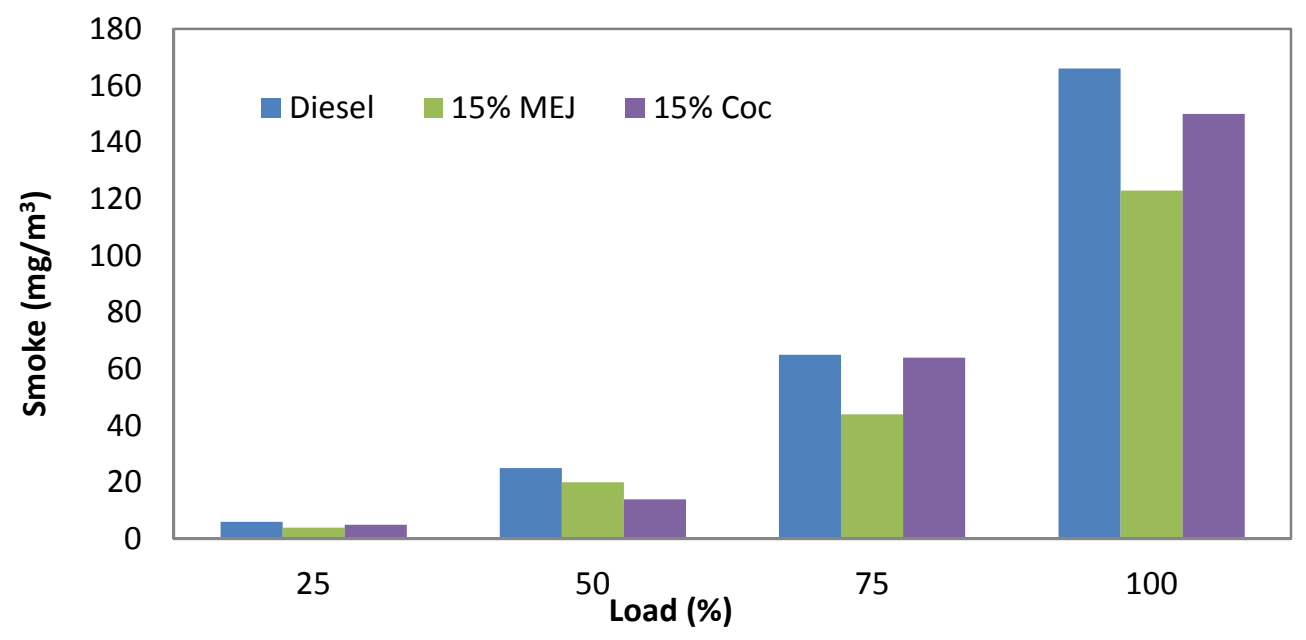

Fig.-4: Variation of Smoke Vs Load

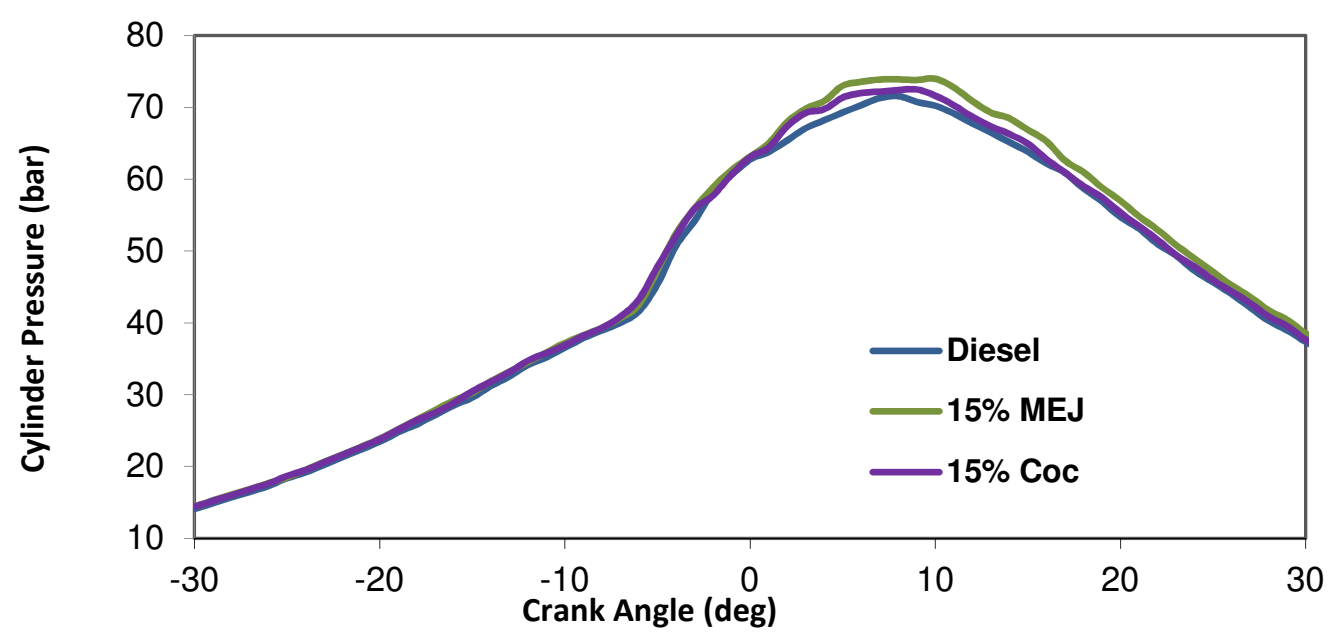

Fig.-5: Variation of Cylinder Pressure Vs Crank Angle

The ignition delay is usually defined as the period from the start of injection to the start of combustion as shown in Fig.-6. Start of injection is given by the engine manufacturer as $23.4^{\circ}$ bTDC (Static injection timing). The start of combustion is the point at which the heat release rate curve starts rising from zero determined from cylinder pressure data. The start of combustion is determined from the AVL indimodule. At rated power output, the ignition delay of diesel, 15\% MEJ and 15\% Coc is determined to be 15.8, 14.86 and $15.54{ }^{\circ} \mathrm{CA}$ respectively. The marginally lower ignition delays for both the methyl ester blends compared to diesel are due to their higher cetane index. The calculated cetane index values for diesel, $15 \%$ MEJ and 15\% Coc are 50, 54 and 53 respectively.

\section{Heat release rate}

The heat release rate is used to identify the start of combustion, the fraction of fuel burned in the premixed mode and differences in combustion rates of fuel ${ }^{19}$. Fig.-7 shows the variation of heat release rate with crank angle at rated power for a diesel, $15 \% \mathrm{MEJ}$ and $15 \%$ Coc methyl esters. It can be observed that prior to the start of combustion the heat release rate is negative for all the fuels tested as the fuel injected absorbs heat for vaporization. It is also observed that the peak heat release rates for MEJ and Coc blends are lower 
than that of diesel. The peak heat release rates at rated power output for diesel, $15 \% \mathrm{MEJ}$ and $15 \% \mathrm{Coc}$ are $77.5,66.5$ and $70.5 \mathrm{~J} /{ }^{\circ} \mathrm{CA}$ respectively.

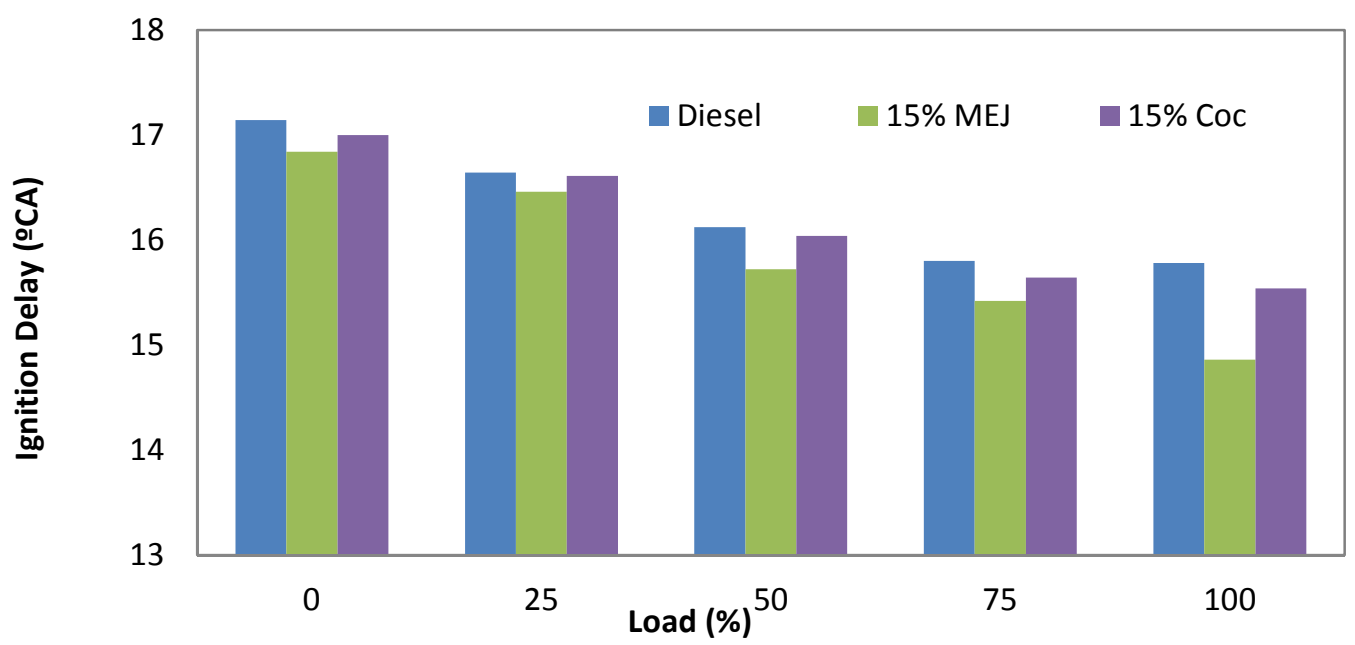

Fig.-6: Variation of Ignition Delay Vs Load

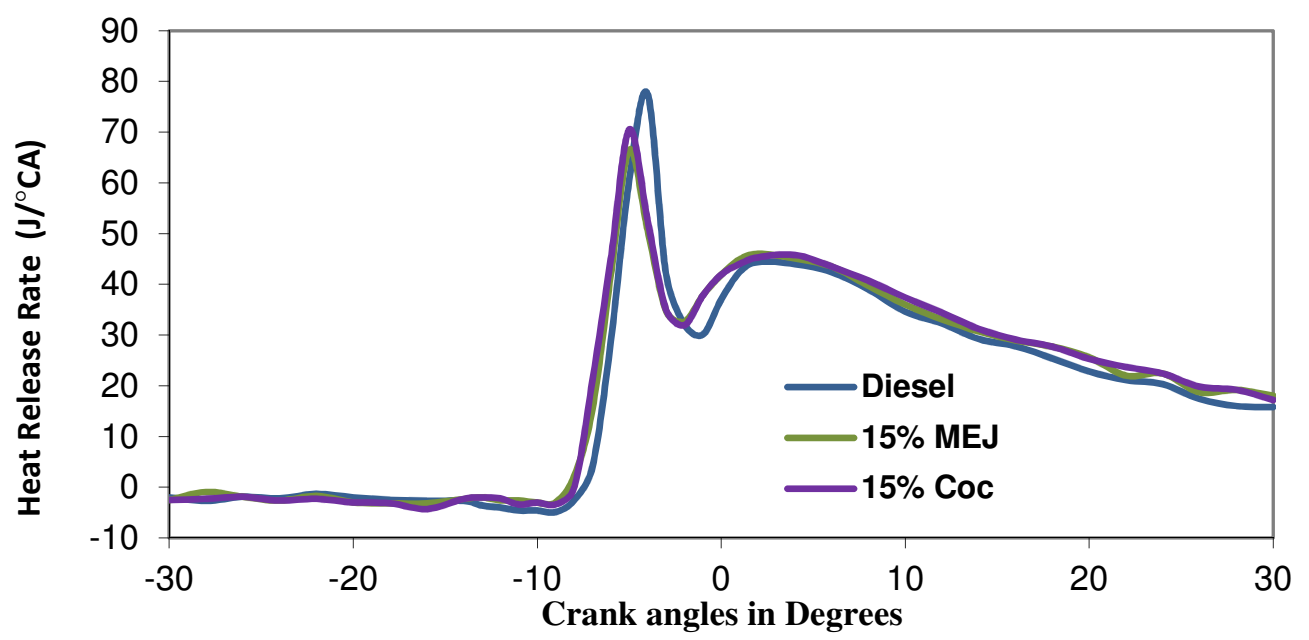

Fig.-7: Variation of Heat Release Rate Vs Crank Angles

\section{CONCLUSION}

The major conclusions drawn from the experiments were the oxides of nitrogen (NOx) increases with a load for all blends. The smoke levels are considerably reduced in de-oiled cake blends. CO emission is considerably reduced at high loads. Specific fuel consumption increases in MEJ and Coc blends, brake thermal efficiency decreases marginally. The MEJ blends show better performance and emission reduction than Coc and Diesel. The MEJ and Coc oils have higher viscosity compared to diesel. Hence, better lubricity than diesel fuel which will reduce the need for lubricity additives being added to diesel fuel. overall, it is concluded that de-oiled cake powders may be used as an oxygenated additive with diesel to improve the performance and emissions of a diesel engine.

\section{REFERENCES}

1. E. Sadeghinezhad, S.N. Kazi, F. Sadeghinejad, A. Badarudin, M. Mehrali, R. Sadri, M. Reza Safaei, Renewable and Sustainable Energy Reviews, 30, 29(2014)

2. J. Ali, A. Semwal, International Journal of Applied Engineering Research, 9(10), 1169(2014)

3. S. Sendilvelan, K. Bhaskar, Rasayan Journal of Chemistry, 9(4), 692(2016) 
RASĀYAN J. Chem.

Vol. 10 | No. 3 |1043 - 1049 | July - September | 2017

4. A.M. Liaquat, H.H. Masjuki, M.A. Kalam, I.M.R. Fattah, M.A. Hazrat, M. Varman, M. Mofijur, M. Shahabuddin, Procedia Engineering,56, 583(2013)

5. S. Sendilvelan, K. Bhaskar, Rasayan Journal of Chemistry,10 (1), 111(2017)

6. C.S. Raj, S. Arul, S. Sendilvelan, C.G. Saravanan, Energy Sources Part A-Recovery Utilization and Environmental Effects, 32(17), 1603(2010)

7. S. Sendilvelan, K. Bhaskar, S. Nallusamy, Rasayan Journal of Chemistry, 10(2), 454(2017)

8. R. Murali Manohar, M. Prabhahar, S. Sendilvelan, European Journal of Scientific Research, 76 (3), 327(2012)

9. L. Prasad, P.M.V. Subbarao, J.P. Subrahmanyam, Applied Thermal Engineering, 63 (1), 379(2014)

10. X.C. Lü, J.G. Yang, W.G. Zhang, Z. Huang, Energy and Fuels, 19 (5), 1879(2005)

11. S. Sendilvelan, K. Bhaskar, Rasayan Journal of Chemistry, 10 (1), 111(2017)

12. A. Agrawalla, S. Kumar, R.K. Singh, Bioresource Technology, 102 (22), 10711(2011)

13. S. Sendilvelan, K. Rajan, Rasayan Journal of Chemistry, 10 (1), 190(2017)

14. H.C. Ong, A.S. Silitonga, H.H. Masjuki, T.M.I. Mahlia, W.T. Chong, M.H. Boosroh, Energy Conversion and Management, 73, 245(2013)

15. N. Nithyanandan, S. Sendilvelan, K. Bhaskar, N. Balaji, S. Mohanamurugan, International Journal of Applied Engineering Research, 5(3), 441(2010)

16. S.A. Shahir, H.H. Masjuki, M.A. Kalam, A. Imran, I.M.R. Fattah, A. Sanjid, Renewable and Sustainable Energy Reviews, 32, 379(2014)

17. E. Sánchez-Arreola, G. Martin-Torres, J.D. Lozada-Ramírez, L.R. Hernández, E.R. Bandala-González, H. Bach, Renewable Energy, 76, 143(2015)

18. H. Omidvarborna, A. Kumar, D.S. Kim, Fuel Processing Technology, 140, 113(2015)

19. A. Sharma, S. Murugan, Journal of the Energy Institute, 88 (4), 364(2014)

[RJC-1703/2017] 